This is an uncorrected draft - cite published version available at Taylor \& Francis Online:

Luke William Hunt (2021), "Policing, Brutality, and the Demands of Justice," Criminal Justice Ethics, DOI: https://doi.org/10.1080/0731129X.2021.1893930 


\section{Policing, Brutality, and the Demands of Justice}

\section{LUKE WILLIAM HUNT*}

Why does institutional police brutality continue so brazenly? Criminologists and other social scientists typically theorize about the causes of such violence, but less attention is given to normative questions regarding the demands of justice. Some philosophers have taken a teleological approach, arguing that social institutions such as the police exist to realize collective ends and goods based upon the idea of collective moral responsibility. Others have approached normative questions in policing from a more explicit social-contract perspective, suggesting that legitimacy is derived by adhering to (limited) authority. This article examines methodologies within political philosophy for analyzing police injustice. The methodological inquiry leads to an account of how justice constrains the police through both special (or positional) moral requirements that officers assume voluntarily, as well as general moral requirements in virtue of a polity's commitment to moral, political and legal values beyond law enforcement and crime reduction. The upshot is a conception of a police role that is constrained by justice from multiple foundational stances.

Keywords: justice, human rights, policing, brutality, dignity, legitimacy

George Floyd was killed by a police officer in Minneapolis, Minnesota, on 25 May 2020. The officer knelt on Floyd's neck for over eight minutes while Floyd-who was handcuffed -exclaimed that he could not

\footnotetext{
*Luke William Hunt, Assistant Professor, Department of Philosophy, University of Alabama, Tuscaloosa. Email: lwhunt@ua. edu
}

breathe. When Floyd became unresponsive, the officer continued to use his knee to pin Floyd's neck to the asphalt street. By any measure, the killing should be remarkable in a liberal society such as the United States. But even at this late stage in the twenty-first century, police brutality continues with alarming frequency. Indeed, the officer who killed Floyd acted with calm resolve in broad daylight, seemingly 
unconcerned that his actions were being filmed by citizens who pleaded for him to let Floyd breathe. ${ }^{1}$

Why does institutional police brutality continue so brazenly? Criminologists and other social scientists typically theorize about the causes of such violence, but less attention is given to normative questions regarding the demands of justice. The burgeoning philosophical interest in policing suggests a variety of ways to evaluate these questions. Some have taken a teleological approach, arguing that social institutions such as the police exist to realize collective ends and goods based upon the idea of collective moral responsibility. Others have approached normative questions in policing from a more explicit social-contract perspective, arguing that legitimacy is derived by adhering to (limited) authority.

After sketching a brief history of 115 policing and brutality, this paper begins by examining methodologies within political philosophy for analyzing police injustice. The methodological inquiry leads to the view that justice constrains the police through both special (or positional) moral requirements that officers assume voluntarily, as well as general moral requirements that constrain the police in virtue of a polity's commitment to concepts such as personhood and human dignity.

Given the proliferation of cases in the United States that have received international attention, this paper focuses on policing in the US rather than attempting a comprehensive comparative analysis of policing around the world. However, there are moral, political, and jurisprudential resonances among different states and cultures (such as human dignity and the rule of law) that connect various manifestations of policing philosophically. Moreover, the methods of political philosophy examined herein may be applied to a variety of states with a variety of institutional commitments. This paper thus raises questions that virtually all societies must ask.

\section{A Brief History of Policing and Brutality}

A multitude of factors have contributed to the police's violent evolution.
Dramatic changes in society -including cultural, industrial, economic, and technological revolutions-over the last two centuries cannot be overstated. The police's role in these revolutions varies considerably from place to place, though it is particularly noteworthy that the police have roots in practices such as slave patrols and strikebreaking in the US. $^{2}$ Subsequent progressive movements focused upon addressingoften through the police-a number of emerging problems stemming from industrialization, urbanization, and prohibition, including class and ethnic conflict, organized crime, and political corruption. ${ }^{3}$ In short, modern policing emerged-with mixed results-during a time of significant change and social friction.

Sir Robert Peel, a British statesman who served twice as Prime Minister in the middle of the nineteenth century, is credited with a series of principles that guided the newlyformed London Metropolitan Police in 1829. The establishment of the Metropolitan Police is often characterized as the advent of modern, 
democratic policing because the Peelian principles implied legitimacy, trust, equality, restraint, and the sanctity of life. ${ }^{4}$

In the United States, Theodore Roosevelt has a significant place in police history. Roosevelt served as police commissioner in New York during the so-called progressive era of reform in the late 1890s. In the lead-up to Roosevelt's tenure as commissioner, bruised and bloodied immigrants had testified to the police's brutality and corruption. ${ }^{5}$ Despite a subsequent period of professionalization in the United States and elsewhere, the police continued to rely heavily upon the tools of coercive force and violence to achieve law enforcement ends.

Over the ensuring years, a "war" on crime evolved in conjunction with decades of semi-reform, racism, socioeconomic disparity, and general cultural upheaval-especially the turmoil of the 1960s and beyond. Subsequently, a militarized police "warrior" concept was bolstered by a longstanding commitment to "law and order" policies that were "tough on crime" at the expense of other values and strategies such as legitimacy and public justification. ${ }^{6}$ Even with sweeping professionalization efforts, then, the history of policing is largely a history of strife.

Consider the police killing of Philando Castile, who was shot by the police four years before Floyd's man, was driving his car in a suburb of Saint Paul, Minnesota, when an officer pulled him overalong with his girlfriend and 4-yearold daughter-for having a brake finishes that sentence, the officer has his hand on his own gun and is pulling it out of the holster. Before being shot, Castile had exclaimed, "I'm not pulling it out." Castile-an elementary school lunchroom worker-had a lawful permit to carry his handgun, which was subsequently found in his pocket on his dead body. ${ }^{7}$

The Minnesota police officer who shot and killed Castile had attended a training course called "The Bulletproof Warrior." These courses teach officers to be less hesitant to use lethal force, urging them to be willing to use it more quickly and teaching them how to adopt the mentality of a warrior. ${ }^{8}$ Of course, the historical development of policing is not defined by a selection of brutal incidents, but these cases help illuminate the extent to which policing has prioritized law enforcement and coercive power over other political values and principles. This idea will be revisited in section IV.

A final point, then, about the history of policing that is occasionally overlooked: Policing is more than coercive law enforcement. When there is an accident on the interstate, who is typically the first to respond? It is very likely the police, who assist their communities by addressing emergency situations as emergency operators. The police are also social enforcers, given that they respond to incidents such as nonlaw-enforcement domestic disputes. Police use their coercive power not just to investigate crime, but also to address other human problems that require the use of force. ${ }^{9}$

Given the police's broad role in society-and their history of brutal community interactions - there have been calls to "defund" (or even light out. Castile is heard saying, "Sir, I have to tell you, I do have a firearm on me." Before Castile 
"abolish") the police. ${ }^{10}$ The idea is to reallocate police funds to other social service organizations that are more skilled at handling non-law enforcement situations. Such reforms are not the topic of this paper, though it is plausible to think that policing will continue to include many non- law enforcement roles for the foreseeable future. This means that brutality is not only a philosophical question, but a pressing practical question. With this backdrop in mind, the following sections consider brutality in light of the demands of justice.

\section{Methodology and Ideology}

If some law enforcement practices lead to brutality, how should those practices be critiqued considering competing values and principles? Political philosophers take a variety of approaches, which often entail balancing the demands of ideal theories of justice (theories based upon idealized assumptions about a society, citizens, and social conditions) and nonideal theories of justice (theorizing in a way that deals with the world as it actually exists).

\section{Policing and Transitional Governance}

$300 \quad$ One prominent methodology-transitional nonideal theory-is based upon the position that ideal and nonideal theory should work together. ${ }^{11}$ John Rawls put it this way: "[U]ntil if the ideal cannot be accomplished, then, it provides a goal and constraints on the path to remedy injustice.

If one evaluates police injustice commitment to reasonable pluralism that allows for an overlapping consensus of views within a diverse society. ${ }^{13}$ Consider how the police are required to interact with a diverse array of persons and backgrounds-from ethnicity, religion, and politics, to mental health, gender, and sexual orientation. It is thus reasonable to think that communities should be policed according to laws, policies, and regulations that can be justified to each member-despite the diversity of backgrounds. Of course, police strategies and tactics (and policies seeking to remedy injustice generally) must also be effective under transitional nonideal theory. In other words, the policies should actually work. ${ }^{14}$

The first two tenets of transitional nonideal theory-political possibility and efficacy - tend to involve social and historical examinations of actual doctrine and practice (such as the law and policies discussed in section IV.1). This is an area in which evidence-based research in criminology and other social sciences is particularly helpful. On the other hand, suppose that effectively increasing security in a diverse community involves the police's pursuit of tactics that are brutal or an affront to one's dignity? Our political under this approach, policies seeking to address injustice should first be politically possible given a 
theory must then consider moral questions regarding the extent to which security, legitimacy, human dignity, and other values may be balanced within society.

Accordingly, transitional nonideal theory requires that policies seeking to address injustice must be morally permissible and prioritize grievances based upon severity. ${ }^{15}$ To be sure, there will be disagreement regarding which policing tactics are morally permissible in liberal societies. Transitional nonideal theory prioritizes grievous (over less grievous) injustices in terms of a lexical ordering of political principles (to put it in Rawlsian terms). If we assume that the foundational ideal of political societies is a particular conception of persons-a conception based upon, say, one's equal status, moral worth, and human dignity - the priority rule is personhood. ${ }^{16}$ For example, stopping property crime is a morally permissible goal given the value of security. However, policing tactics that are an affront to one's personhood would be precluded given 390 that one's equal status, moral worth, and dignity are prioritized over reducing automobile theft.

One might object that policing and ideal theory do not fit together ized assumptions about society, but it is inevitable that some people will act unjustly even in an operative ideally just society (given, say, fundamental truths about societies and

\section{of security requiring law enforcement. $^{18}$ \\ 2. Policing and Social Contractarian Ideals}

Transitional nonideal theory is often steeped in social contract theory: certain tasks (such as policing) are entrusted to agents of the collective in order to permit a mutually beneficial (and morally justified) division of labor. This is said to result in a right to be secured legitimately and within the limits of the state's authority. ${ }^{19}$

Although theories of legitimacy abound, consider the way that transactional theories (such as those based upon reciprocation and fairness) are related to the limits of policing. The basic idea is that-as reciprocators within a collectivewe are all presumed to have a fair share of the collective labor. This also means that persons are viewed as having a general duty to the collective because it would be wrong to reap the benefits as a "free rider" who takes advantages of others' good-faith compliance. ${ }^{20}$ This is a relatively standard position in political philosophy, with Jonathan Jacobs writing that "it is reasonable to think that any plausible conceptions [of a well-ordered or healthy civil society] require people to... cooperate in a variety of settings... [and] be capable of decently effective practical reasoning with respect to their own interests and with respect to the interests of family members, associates, organizations, and groups." 21 What are the normative contours of the state's response to breakdowns in civil society?

Policing is raised when people choose not to reciprocate, as when human psychology). It is thus unsurprising that ideal theory might have something to say about emergencies 
one interferes with another's liberty or the community's security. A prominent ideal within liberal polities is that failed reciprocation is dealt with in accordance with the rule of law and respect for one's personhood and human dignity. ${ }^{22}$ This contrasts with dealing with law-breakers through unjustified or arbitrary police punishment and discretion, as when the police act under the pretense of law. ${ }^{23}$

\section{Other Approaches}

Of course, there are many fruitful ways to approach problems in policing from within the context of political philosophy. For example, one might seek progress in policing by emphasizing (actual, historic) institutional values rather than unrealized ideals. My sense is that political theorizing about liberal ideals and historic values regarding actual, liberal institutions (such as the police) are deeply connected. Consider, say, Ronald Dworkin's position that theorizing should focus not only on history, but also on the best understanding and interpretation of legal and political principlesmeaning that the truth value of legal and political propositions is based upon both descriptive statements about what the propositions are and evaluative statements about what they should be. ${ }^{24}$

Alternatively, consider Jacobs's account of the relationship between civics ("fundamental values and principles concerning the political/legal order") and policy ("actual practices and administrative procedures"): Any concrete steps regarding policy "will involve assumptions and have implications regarding fundamental issues of civics." ${ }^{25}$ By analogy, it seems plausible that aspirational ideals will draw from the fundamental values and principles of civics, as I have noted elsewhere: "transitional nonideal theory addresses practical questions ... in part through the lens of theory that is informed by historical ideals ... it acknowledges that the practicality of ideal political theory is a function of the theory's viability in the context of actual, historic conditions." 26 The point is that we can often find common ground among seemingly disparate approaches.

Other philosophers of policingsuch as Seumas Miller-have pursued teleological arguments with respect to social institutions generally and the police institution specifically. This means that the police are evaluated based upon the extent to which they realize collective ends and produce collective goods given collective moral responsibility. ${ }^{27}$ More recently, John Kleinig has focused upon the philosophical importance of ends and means in policing. In other words, perhaps our focus should be on the relationship between core social ends (such as security and crime reduction) and the concrete means through which those ends are achieved by the police-such as force, deception, and discretion. ${ }^{28}$

Each of these approaches (among others) is different in important ways, and it is beyond the scope of this paper to explore the differences in detail. The commonality is competing moral demands within political society. For this reason I continue to return to transitional nonideal theory, which incorporates the practical considerations of political possibility and efficacy in a way that is constrained by moral considerations regarding the basic tenets of an 
ideal theory of justice. But theory of justice has been sufficiently one problem that must be worked out to guide our nonideal addressed is whether an ideal theorizing. ${ }^{29}$

\section{Political, Legal, and Moral Obligations in Policing}

Transitional nonideal theory needs a target for which to aim. Although one need not embrace a Rawlsian ideal theory of justice-or any other particular theory-one does have to make some basic assumptions about what an ideal theory of justice would entail. As alluded to in section III.1, I take the plausible view that a conception of persons will be at the core of any ideal theory of justice.

560 Such conceptions traditionally have been based upon the value of natural human properties such as rationality and voluntariness (as with Kant and Locke), which give 565 rise to conceptions of freedom, equality, and dignity. Rawls put it this way: "[I]n virtue of their two moral powers (a capacity for a sense of justice and for a conception of the good) and the powers of reason (of judgment, thought, and inference connected with these powers) persons are free. Their having these powers to the requisite minimum degree to be fully cooperating members of society makes persons equal." 30 These and similar conceptions of persons give rise to both special and general moral obligations, which help guide nonideal theorizing and the demands of justice.

\section{Positional Obligations in Policing: Law and Policy}

Special and positional requirements are grounded in (or arise within) those relationships that we have (or freely make) with persons or groups. ${ }^{31}$ If a police officer fails to do his duty as police officer, then he is morally blameworthy because he voluntarily entered his position and undertook the duties of that position. Unlike most people, then, one of the explicit special obligations of the police is to obey the law.

Given recent attention to policing in the United States, consider how the police are constrained by legal obligations derived from the Constitution. The Fourth Amendment to the US Constitution protects the "right of the people to be secure in their persons ... against unreasonable ... seizures." A police officer's use of force (deadly, or otherwise) constitutes a seizure and must be reasonable. Courts have construed the "reasonableness" of force based upon "the perspective of a reasonable officer on the scene, rather than with the $20 / 20$ vision of hindsight." ${ }^{\prime 32}$

This allows for broad deadlyforce polices, meaning that much of the police's day-to-day conduct is more directly governed by regulations and internal policy. ${ }^{33}$ For example, here is the policy I learned while training to be a Special Agent at the FBI Academy at Quantico: "Special agents may use deadly force only when necessary-when the agent has a reasonable belief that the subject of such force poses an imminent danger of death or serious physical injury to the agent or another person." ${ }^{34}$ The language 
tracks the expansive "reasonableness" of the Constitution and case law, but this minimum requirement could be enhanced at the policy level. ${ }^{35}$

By any standard, the officer who killed George Floyd breached his special positional obligation to follow law and policy. There was no threat of harm (Floyd was laying flat on the ground, handcuffed), and his actions (kneeling on Floyd's neck for over eight minutes) were clearly unreasonable and unnecessary. This raises the important point that the police's positional obligations go beyond legal obligations.

Consider the case of Eric Garner, who the police arrested for the charge of selling loose cigarettes illegally (without tax). When Garner pulled away from being handcuffed, it was reported that "[t]he officer immediately threw his arm around 655 [Garner's] neck and pulled him to the ground, holding him in what appears, in a video, to be a chokehold. The man can be heard saying 'I can't breathe' over and over again as other officers swarm about." ${ }^{36} \mathrm{~A}$ grand jury decided not to indict the officer who killed Garner because there was no law prohibiting the officer's use of a chokehold. But that does not address the (policy and moral) problem regarding the police's use of discretion to arrest Garner for a minor offense that immediately escalated to the use of an unauthorized

Ironically, even if such tactics are not against the law-only policythey raise questions about a person's most basic, human rights. One pro- human dignity. ${ }^{37}$ This raises the issue of general moral obligations in policing.

680

\section{Human Dignity and General Obligations in Policing}

In addition to positional obligations, justice may constrain the police through a polity's commitment to general (non-voluntary) moral requirements that bind the police in virtue of another's personhood and moral equality, irrespective of special roles or relationships. ${ }^{38}$ There are a variety of theories about what grounds general moral requirements, including human dignity (a person's priceless worth, or highranking, equal, social status) and natural rights (rights that would exist in a pre-institutional state of nature). ${ }^{39}$ Such general moral requirements might bolster a commitment to human rights, which could be grounded in those natural or political rights that enable persons to live with dignity. ${ }^{40}$

Although various conceptions of dignity may have overlapping features, there are several distinct ways to think about dignity. Doris Schroeder has identified at least five, which include Kantian Dignity ("a property of all rational beings, which gives the possessor the right never to be treated simply as a means, but always at the same time as an end"), Aristocratic Dignity ("the outwardly displayed quality of Q3 a human being who acts in accordance with her superior rank and position), and Comportment Dignity ("the outwardly displayed quality of a human being who acts in accordance with society's expectations of wellmannered demeanor and bearing" ${ }^{\prime 4}{ }^{41}$ minent view discussed in the next section is that human rights are grounded in natural rights and 
These conceptions often overlap, which is apparent in the policing domain. Although the police may be justified in treating a person in a particular way based upon the person's comportment (say, resisting arrest), it must be done in a manner that does not denigrate the rights comprised by the person's high-ranking, equal, social, and legal status. In a similar way, the police's use of informants is perhaps an indispensable investigative tool, but there are moral limits to the police's power to use persons (informants) as a means to a law enforcement end given a person's status and value emanating from dignity. ${ }^{42}$

How is human dignity related to human rights, and how are human rights related to policing? There is of course much disagreement about the nature and foundation of human rights, but here are three possibilities regarding their nature and foundation: They are either (1) derived from human dignity, (2) derived from natural rights, or (3) derived from the practical political conceptions and concerns of international politics.

Some political and legal philosophers think of dignity as a status concept resulting in a particular package of (human) rights that a person has in virtue of being human. ${ }^{43}$ Other accounts of human rights draw from the natural rights tradition-such as the Kantian and

760 Lockean traditions-arguing that pre-institutional natural rights count as "equal and inalienable" rights of all human persons. ${ }^{44}$ Such accounts are especially relevant within the political institutions. The upshot would be a natural right to legitimate institutions, requiring us to mitigate the illegitimacy of institutions such as the police.

Although these and other questions about human rights remain unsettled, I want to now consider how the basic tenets of any theory of human rights and human dignity might be applied in the context of policing. ${ }^{45}$

First, human rights may be construed as claim rights in this policing context because they impose duties of treatment on the police. For example, if security of person is a human right, then it is a claim right on other people-in this case, the police-to respect one's liberty. I thus have a claim right against the police not to use force against me or seize me. On the other hand, the police have the power to alter my right and seize me (with legitimate force) if I break the law, though I am immune from brutality given that the police have no legitimate power to alter my security of person through brutal force. ${ }^{46}$

Human rights are thus political rights in the policing context because the police (as duty-bearers) have power over right-holders. One's human right to security of person may be violated in a multitude of (non-political) ways, but such a right is uniquely violated when the police harass, assault, and brutalize persons under "color of law" (acting under the pretense of state authority). ${ }^{47}$ It thus seems plausible to think that any justified conception of the police role includes pursuing justice in a way that respects one's human right to security of person.
770 
Given the assumptions discussed above, it stands to reason that we would treat-in addition to security of person-governance by legitimate authority as a human right that is relevant in the domain of policing. It would be impractical to wade further into the voluminous literature on legitimacy, and I will simply assume that legitimacy is fundamentally about appropriate authority to wield power over a person. ${ }^{48}$ This approach shows the deep connections between police legitimacy and broader notions of state legitimacy. For instance, a police officer detaining a person during a "stop and frisk" acts as an agent of the state. Accordingly, when the police act without requisite authority (an unconstitutional "stop and frisk"), their acts are illegitimate because they are not acts of the state; they are outside the rule of law and without authority.

The upshot is a natural overlap between certain human rights and certain political and civil rights-as when the police have a general moral requirement not to brutalize persons, which is also prohibited by their special, positional duties as police. ${ }^{49}$

\section{Reforms and Conclusions}

It should go without saying that reforming the police is a difficult problem that requires a holistic, multifaceted approach. The difficulties are exacerbated by the fact that police agencies and officers vary widely, from uniformed patrol officers to "plainclothes" detectives and other investigators who pursue investigations spanning many years. The complexities of politics and jurisdiction raise different problems for "local" police who have jurisdiction over town and county matters, "state" police who have jurisdiction over state matters, and federal law enforcement officers who have jurisdiction over matters that have a national or international nexus, and so on.

Despite the wide range of officers and agencies, it is possible to identify overlapping tenets that constrain law enforcement given the demands of justice. Although I cannot address all the relevant considerations in a single article, I close by sketching three domains in which policing might be reoriented to a broader

ideal of justice: law, police culture, and politics. ${ }^{50}$

\section{Legal Reform}

Holding police accountable for misconduct has long been a problem given the law of qualified immunity: a judicially created doctrine shielding the police (and other government officials) from being held personally liable for money damages due to constitutional violations (such as brutality), assuming the police did not violate "clearly established" law. ${ }^{51}$

Legal scholars have argued that the best way to reform qualified immunity is legislatively because the doctrine is primarily based upon statutory (not constitutional) interpretation. ${ }^{52}$ On the other hand, qualified immunity does not affect police misconduct that does not rise to a constitutional violation, meaning that reform of state tort law (regarding, say, statutory privileges and indemnification regulations) should also be considered. ${ }^{53}$ 


\section{Cultural Reform}

Policing is a unique profession in part because it includes the use of violence and force. A sense of professional exclusivity has resulted in unique cultural problems such as the prevailing police warrior identity. $^{54}$ Such cultural issues are complex and difficult to address,

\section{Political Reform}

Politics-local and national-is perhaps the most difficult obstacle for police reform. Some commentators have linked the police's extensive collective-bargaining rights to watered-down legislative reform, not to mention increases in violent police misconduct. To be sure, police unions have secured many contractual protections regarding officer exposure to disciplinary action (including policies erasing disciplinary records), making it difficult to hold officers accountable. Reform is difficult given the influence that unions hold over politicians, but one inclusive, community-based idea is to involve members of the public in police contract negotiations. ${ }^{57}$

There are also political impediments to police reform that are even more systemic. Some commentators view the problems in policing as being connected to broader political, social, and economic forces. For example, consider the number of firearms in the United States, which is of course a broad political issue outside of policing. Likewise, the police are often tasked with focusing their law enforcement role on impoverished communities that have experienced generations of systematic oppression. ${ }^{58}$ The police cannot change the economic and political policies that create and sustain stratification in states such as the U.S., nor can they unilaterally shift their attention to the crimes that prop up that stratification (such as white-collar crime and government fraud and corruption).

This is related to the important point that the police are often asked to enforce politically unpopular laws (such as drug laws), which can put the police in a difficult position with the public. Police discretion is an important and necessary component of the police role (imagine if 
the police had to enforce all speeding violations), but the answer to unpopular laws is not necessarily an expansion of police discretion (such as the discretion to not enforce unpopular laws). There is good law and there is bad law, but Joseph Raz's point about the rule of law and the limits of discretion seems apt here: "The discretion of the crime-preventing agencies should not be allowed to pervert the law." ${ }^{59}$ Accordingly, a more realistic (politically possible) and procedurally just approach might be for the police to begin by taking remedial action to reduce the extent to which they unfairly and unjustly impose unpopular laws on the community. ${ }^{60}$

For example, the police might (1) prioritize the most grievous injustices-such as violent crime and affronts to one's security of person generally-over, say, possession of drugs; and (2) enforce all laws (drug laws or otherwise) in accordance with the rule of law and in a way that respects one's equal social status and moral worth (rather than targeting or exempting some groups based upon class and ethnicity). ${ }^{61}$ Related constraints would include respecting the human dignity of all persons (including informants and criminal suspects), and reducing unnecessary operations that pervert the law (e.g. unnecessary drug buys that require sanctioned law-breaking by the police). In short, it is plausible to think that the first order of business is for the police to take remedial action reducing the way they unfairly and unjustly enforce unpopular laws. Of course, this will ultimately result in less-or different-enforcement, though for reasons that are in keeping with a principled transition toward a holistic ideal of justice.

\section{Justice in Policing}

Given the general and special obligations that have been discussed, there is good reason for the police to pursue their role in ways that goes beyond a utilitarian focus on security and crime reduction. Specifically, these obligations compel the police to respect human dignity and seek public justification for their power in order to enhance legitimacy. One practical way to do this is a renewed emphasis on established policing strategies-such as community and procedural justice policing-that seek community support and buy-in through public reason. $^{62}$

Whatever approach is taken with respect to reform, I hope it is clear that the problem of police brutality is more complicated than it might first appear. Courts have given the police much leeway with respect to the use of (deadly) force given that police must make "split-second" decisions about the use of such force. $^{63}$ This does not mean that reform is impossible, though it does mean that we must turn our attention to the minutes, hours, weeks, and months leading up to deadly force encounters. Better recruitment, training, and operational tactics - prioritizing de-escalation, human dignity, the sanctity of life, and other principles of justice-can help the police avoid encounters that lead to brutality and deadly split-second decisions.

Despite the complexities, then, I will try to put my conclusion straightforwardly: The police have both positional and general 
obligations that have multiple foundations-moral, political, and legal. The sort of conduct that led to George Floyd's death thus raises questions on a number of fronts, requiring a multifaceted approach that aims for a holistic conception of justice.
1085

\section{Acknowledgement}

This article draws from and distills some of the central ideas in my two books on policing. I am grateful to
Jonathan Jacobs for his thoughtful comments throughout an early draft.

\section{Notes}

Q4 [Disclosure Statement: No potential conflict of interest was reported by the author(s).]

1 Many of the events surrounding Floyd's death were captured on video and can be viewed on the internet.

2 See Gourevitch, "Why Are the Police Like This?"

\section{See McGerr, Fierce Discontent.}

4 See Adegbile, "Policing Through an American Prism," 2232.

5 See Berman, Police Administration and Progressive Reform.

6 See Balko, Rise of the Warrior Cop; and Friedman, Unwarranted.

7 Like Floyd's death, the police's killing of Castile was captured on video and can be viewed on the internet.

8 See Smith \& Williams, "Minnesota Police."

9 See Kleinig, Ethics of Policing. More holistically, Kleinig has characterized the police as social peacekeepers. This conception of the police focuses upon the responsibility of maintaining security (or peace) in a way that is consistent with the limits of the state's legitimate power. In other words, keeping the peace involves building trust by the appropriate use of discretionary power, including discretionary law enforcement power.

10 See Ray, "What does 'defund the police' mean?"

11 See Simmons, "Ideal and Nonideal Theory."
12 Rawls, Law of Peoples, 90.

13 I have raised Rawls's transitional nonideal theory (in other words, constraints requiring us to address actual injustices in the world by pursuing policies that seek transition to an ideal of justice), which is methodological in nature. The underlying methodology might be relevant to a variety of substantive commitments, so we need not dwell upon Rawls's substantive commitments of justice (or the voluminous literature regarding those commitments). Nevertheless, one might still have reservations about whether an idea such as "overlapping consensus" is as important as the state simply protecting one's ability to lead a life shaped by values one regards as crucial. The extent to which such ideas converge is disputed, and the issue is beyond the scope of this paper.

14 See Rawls, Law of Peoples, 89.

15 See ibid.; Rawls, Theory of Justice, 267.

16 See Hunt, Retrieval of Liberalism in Policing, chapter 3.

17 I thank Jake Monaghan for raising this worry during my talk at the American Philosophical Association, Central Division meeting, in Chicago in February 2020.

18 See Hunt, Police Identity Crisis, Epilogue.

19 See Locke, Two Treatises of Government, 330-33; Hunt, Retrieval of Liberalism in Policing, $106_{-} 14$. 
20 See Wellman and Simmons, Is There a Duty?

21 Jacobs, "Civics, Policy, and Demoralization," 41.

1175

22 See Fuller, Morality of Law; Raz, Authority of Law.

23 Hunt, Retrieval of Liberalism in Policing, $85-90$.

1180

24 See Dworkin, Law's Empire, 225, where Dworkin argues that the process of determining the truth value of legal and political propositions requires an interpretive reasoning based upon both facts and moral principles of the community. See also Hunt, "What the Epistemic Account," $40-46$, for an analysis of Dworkin's law as integrity and right answer thesis.

25 Jacobs, "Civics, Policy, and Demoralization," 41.

1190

26 Hunt, Retrieval of Liberalism in Policing, 77 - 8 .

27 See Miller, Moral Foundations, 153.

28 See Kleinig, Ends and Means.

1195

29 See Sreenivasan, "Health and Justice," 221.

30 Rawls, Political Liberalism, 19.

31 Rawls, A Theory of Justice, 97- 9 .

32 Graham v. Connor, 490 U.S. 386 (1989).

33 See Harmon, "Problem of Policing"; Joh, "Breaking the Law."

34 Federal Bureau of Investigation, "What is the FBI's policy on the use of deadly force by its special agents?" https:// www.fbi.gov/about/faqs/what-is-the-fbispolicy-on-the-use-of-deadly-force-by-itsspecial-agents\#: :text=FBI\%20special\% 20agents $\% 20$ may $\% 20$ use, the $\% 20$ agent $\%$ 20or\%20another\%20person
35 See Hunt, Police Identity Crisis, chapter 4 .

36 Goldstein and Schweber, “Man's Death after Chokehold."

37 See Hunt, Police Identity Crisis, chapter 4 , for a more comprehensive discussion of the role of human rights in policing.
38 See Rawls, Theory of Justice, 97-99.

39 See Waldron, Dignity, Rank, and Rights. One might ask whether concepts and values such as dignity, liberty, privacy, equality, and so on, need to be conceptualized in an ideal manner in order to discern their full importance. Although such questions are beyond the scope of this paper, it seems reasonable to think that we know enough about a broad outline of an ideal theory of justice to permit coherent nonideal theorizing, e.g., an ideal theory of justice would include some commitment to human dignity, even if we cannot yet agree upon a fully worked-out theory of human dignity. Relatedly, questions about how human dignity is connected to human rights (and whether human rights are grounded in human dignity) is a disputed issue, as I note in this paper. Many have argued that human rights are primarily about issues in international political philosophy, such as the justification and legitimacy of a state intervening in the affairs of another state. It thus seems right to say that civil rights are most directly related to policing, though it also seems plausible that they overlap with more basic human rights that are relevant to moral questions in policing.

40 See Simmons, "Human Rights, Natural Rights."

41 Schroeder, "Dignity: Two Riddles," $230-38$.

42 See Hunt, Retrieval of Liberalism in Policing, chapter 4 .

43 See Waldron, "Is Dignity the Foundation?"

44 See Simmons, "Human Rights, Natural Rights."

45 Other accounts of human rights include Rawls's implicit critique of foundational theories, suggesting a "practical" conception of human rights based upon the pressing concerns of domestic and international politics (rather than historical, pre-institutional natural rights). See Rawls, Law of Peoples; Beitz, Idea of Human Rights.

46 See Hohfeld, "Fundamental Legal Conceptions."

1220

1225

1230

1235

1240

1245

1250

1255

1260 
47 See Hunt, Retrieval of Liberalism in Policing, $22{ }_{\bar{\Delta}} 3$.

48 See Wellman \& Simmons, Is There a Duty?

1265

1270

1275

1280

1285

1290
49 See Hunt, Police Identity Crisis, chapter 2 and 4.

50 See Hunt, Police Identity Crisis, Epilogue.

51 See Bivens v. Six Unknown Named Agents, 403 U.S. 388 (1971); 42 U.S.C. Code $\S 1983$. More generally, public tort law governs civil wrongs by officials resulting in harm or loss by a claimant.

52 See Michelman, "Branch Best Qualified."

53 See Stern, “Tort Justice Reform.”

54 See Hunt, Police Identity Crisis, chapter 2.

55 See Jackman, “New Orleans police pioneer."

56 See Hunt, Police Identity Crisis, which various understandings of the police role and identity.

57 See Greenhouse, "How Police Unions Enable."

58 See Shelby, Dark Ghettos. provides a comprehensive analysis of
Adegbile, Debo P. "Policing through an American nrism." Yale Law Journal 126, no. Q5 7 (2017): 2222-59.

1 Balko, Radley. The Rise of the Warrior Cop. New York: PublicAffairs, 2014.

Beitz, Charles R. The Idea of Human Rights. Oxford: Oxford University Press, 2009.

Berman, Jay Stuart. Police Administration and Progressive Reform: Theodore Roosevelt as Police Commissioner of New York. Westport: Greenwood, 1987.

Dworkin, Ronald. Law's Empire. Cambridge: Harvard University Press, 1986.

Eisinger, Jesse. 2014. "Why Only One Top Banker Went to Jail for the Financial Crisis." The New York Times, April 30.

Friedman, Barry. Unwarranted: Policing Without Permission. New York: Farrar, Straus and Giroux, 2017.
59 Raz, The Authority of the Law, 218.

60 I thank Jake Monaghan for alerting me to this issue during my talk at the American Philosophical Association, Central Division meeting, in Chicago in February 2020. I also thank Jonathan Jacobs for making a similar point. I address these issues to some degree in Hunt, Police Identity Crisis, chapter 2, which generally follows Rawls, who states in A Theory of Justice: "The injustice of a law is not, in general, a sufficient reason for not adhering to it any more than the legal validity of legislation (as defined by the existing constitution) is a sufficient reason for going along with it. When the basic structure of society is reasonably just, as estimated by what the current state of things allows, we are to recognize unjust law as binding provided they do not exceed certain limits of injustice" (308). Of course, the tricky part is explaining "certain limits of injustice," which I pursue further in The Police Identity Crisis.

61 See Hunt, Police Identity Crisis, chapter 2 .

62 Hunt, "Ice Cube and the philosophical foundations"; Hunt, Police Identity Crisis, chapter 4 .

63 Graham v. Connor, 490 U.S. 386 (1989).
Fuller, Lon L. The Morality of Law. New Haven: Yale University Press, 1969.

Goldstein, Joseph, and Nate Schweber. 2014. "Man's Death After Chokehold Raises Old Issue for the Police." The New York Times, July 18.

Gourevitch, Alex. 2020. “Why Are the Police Like This?" Jacobin, June 12.

Greenhouse, Steven. 2020. "How Police Unions Enable and Conceal Abuses of Power." The New Yorker, June 18.

Harmon, Rachel. "The Problem of Policing." Mich Law Rev 110, no. 5 (2012): 761-817.

Hohf Nesley Newcomb. "Some Fundamental 1 Conceptions as Applied in Judicial Reasoning." Yale Law Journal 23 (1913): 16-57.

Hohfeld, Wesley Newcomb. “Fundamental Legal Conceptions as Applied in Judicial 
Reasoning." Yale Law Journal 26 (1917): 71070.

Hunt, Luke William. "What the Epistemic Account of Vagueness Means for Legal Interpretation." Law Philos 35, no. 1 (2016): 29-54.

1355

Hunt, Luke William. $\overline{\bar{h}}$ Retrieval of Liberalism in Policing. New York: Oxford University Press, 2019.

Hunt, Luke William. 2019. "Ice Cube and the philosophical foundations of community poli-

1360

1365 cing." Oxford University Press Blog, February 17. https://blog.oup.com/2019/02/ ice-cube-philosophical-foundationscommunity-policing/

Hunt, Luke William. The Police Identity Crisis Hero, Warrior, Guardian, Algorithm. New York: Routledge, 2021.

Jackman, Tom. 2019. "New Orleans police pioneer new way to stop misconduct, remove 'blue wall of silence.'” The Washington Post, January 24.

1370

Jacobs, Jonathan. "Civics, Policy, and Demoralization." Crim Justice Ethics 36, no. 1 (2017): 25-44.

Joh, Elizabeth E. "Break the Law to enforce It: undercover police participation in crime." Stanford Law Rev 62, no. 1 (2010): 155-98.

Kleinig, John. The Ethics of Policing. Cambridge: Cambridge University Press, 1996.

Kleinig, John. Ends and Means in Policing. New York: Routledge, 2019.

Locke, John. Two Treatises of Government. Cambridge: Cambridge University Press, 1988.

McGerr, Michael. Fierce Discontent: The Rise and Fall of the Progressive Movement in America, 1870-1920. New York: Oxford University Press, 2003.

Michelman, Scott. "The Branch Best Qualified to Abolish Immunity." Notre Dame Law Review, 93, no. 5 (2018): 1999-2020.

Miller, Seumas. The Moral Foundations of Social Institutions. Cambridge: Cambridge University Press, 2010.
Rawls, John. The Law of Peoples. Cambridge: Harvard University Press, 1999.

Rawls, John. A Theory of Justice. 2nd ed. Cambridge: Harvard University Press, 1999.

Rawls, John. Political Liberalism. 2nd ed. New York: Columbia University Press, 2005.

Ray, Rashawn. 2020. "What does 'defund the police' mean and does it have merit?" Brookings, June 19.

Raz, Joseph. The Authority of Law. 2nd ed. Oxford: Oxford University Press, 2009.

Schroeder, Doris. "Dignity: Two Riddles and Four Concepts." Camb Q Healthc Ethics 17, no. 2 (2008): 230-

Simmons, A. John. "Id 7 a Nonideal Theory." Philes Public Aff 38, no. 1 (2010): 5-36.

Simmons, A. John. "Human Rights, Natural Rights, and Human Dignity." In Philosophical Foundations of Human Rights, edited by R. Cruft, M. Liao and M. Renzo, 138-152. Oxford: Oxford University Press, 2015.

Shelby, Tommie. Ghettos: Injustice, Dissent, and Reform. Cambridge: Harvard University Press, 2016.

Smith, Mitch, and Timothy Williams. 2016. "Minnesota Police Officer's 'Bulletproof Warrior' Training Is Questioned." The New York Times, July 14.

Sreenivasan, Gopal. "Health and Justice in Our Non-ideal World." Politics, Philosophy, $\mathcal{E}$ Economics 6, no. 2 (2007): 218-36.

Stern, Paul D. "Tort Justice Reform." University of Michigan Journal of Law Reform 52, no. 3 (2019): 649-730.

Waldron, Jeremy. Dignity, Rank, and Rights. New York: Oxford University Press, 2012.

Waldron, Jeremy. "Is Dignity the Foundation of Human Rights?" In Philosophical Foundations of Human Rights, edited by R. Cruft, M. Liao and M. Renzo, 117-37. Oxford: Oxford University Press, 2015.

Wellman, Christopher Heath and A. John Simmons. Is There a Duty to Obey the Law? Cambridge: Cambridge University Press, 2005. 